DOI: 10.15393/j9.art.2020.8743

УДК 821.161.1.09+82.01+94(470)“08/16”

А. И. Попович

Уральский федеральньй университет

(Екатеринбург, Российская Федерачия)

alexeypopowich@mail.ru

\title{
«Изображая жертву»: пафос обличения и мученичества в сочинениях Ивана Грозного и Андрея Курбского*
}

Аннотация. В статье исследованы изменения в представлении категорий жертвы и жертвенности в памятниках публицистики второй половины XVI в.: в переписке Ивана Грозного с Андреем Курбским и в «Истории о великом князе Московском» Курбского. Выявлено, что обращение писателей этого времени к литературной топике жертвы имеет принципиально иной характер по сравнению с предшествующей книжностью Древней Руси. В данном аспекте определены основные средства поэтики и риторики сочинений Грозного и Курбского. Приемы актуализации темы жертвы для обоих авторов носят схожий характер: каждому из них свойственна определенная десакрализация высокой христианской идеи и использование ее и связанной с ней топики в субъективных, как правило, идеологических целях. Подобные изменения становятся возможными вследствие характерного для того времени смешения земной (мирской) и небесной (сакральной) логики в обращении с категорией жертвы. Если для Курбского убитые царем люди являются новомучениками, то для самого Грозного это в первую очередь справедливо наказанные изменники. Царь убежден, что подданные должны быть готовы пожертвовать жизнью ради него и по его воле, Курбский же, не отрицая необходимость и готовность к жертве, последовательно доказывает несоответствие личности царя христианским представлениям об идеальном самодержце, тем самым убеждая читателя в возможности противостояния монарху. Оба автора при этом, характеризуя себя как лицо, пострадавшее от действий другого, используют литературную топику жертвы.

Ключевые слова: жертва, жертвенность, топика жертвы, переписка Ивана Грозного и Андрея Курбского, «История о великом князе Московском», вторая половина XVI века

Об авторе: Попович Алексей Игоревич - лаборант-исследователь Лаборатории эдиционной археографии, Уральский федеральный университет (ул. Мира, 19, Екатеринбург, Российская Федерация, 620002)

Дата поступления: 04.05.2020

Дата публикации: 30.10 .2020

Для цитирования: Попович А. И. «Изображая жертву»: пафос обличения и мученичества в сочинениях Ивана Грозного и Андрея Курбского // Проблемы исторической поэтики. - 2020. - Т. 18. — № 4. - С. 67-98. DOI: $10.15393 /$ j9.art.2020.8743 


\section{Жертва: категория и художественный образ}

\ل ертва и жертвенность - важнейшие категории в русской в т. ч. дохристианской, ритуальной практике, они адаптируются к актуальным проблемам времени и, вербализуясь ${ }^{1}$, вбирают в себя актуальное для времени содержание. В книжности Древней Руси на разных этапах коммуникативная и спасительная функция ритуала достраиваются через то или иное предназначение: метафорическое и идеализирующее, обличительное и уничижающее и т. д. При этом не все оттенки представлений о жертве, даже как о понятии или идее, могут быть вербализованы: в сфере ритуала и ощущений (эмоций) присутствует некоторое внетекстовое пространство. Материальный и идеальный миры сложно взаимодействуют, формируя «жертвенное поле» в пространстве текстов и семантике артефактов культуры.

С появлением христианства на Руси книжники, явно имевшие представление о дохристианской идее жертвы и о принятом в родовых обществах варианте самопожертвования, сталкиваются с новой, христианской реальностью и комплексом идей. Смену представлений можно проследить в границах книжности: выявление образно-сюжетной и риторической систем в художественном воплощении архаичной категории оказывается конструктивно при восстановлении контекстов времени (историко-культурного, личностно-биографического, авторско-стилевого и т. п.). Литература при этом работает в первую очередь с художественными категориями ${ }^{2}$. К таковым следует отнести риторическую по своей природе топику. Топос так или иначе отсылает к некоей уже готовой системе и тесно связан с другими ее элементами, С. С. Аверинцев представлял его как «инструмент абстрагирования, средство упорядочить, систематизировать пестроту явлений действительности, сделать эту пестроту легко обозримой для рассудка» [Аверинцев: 159].

Обращаясь к книжности XI-XIV вв., можно обнаружить как минимум два антиномичных представления о жертве: жертвоприношение как проявление «нечистого» материального мира, 
восходящее к язычеству, и добровольная духовная жертва (жертвенность) [Попович]. Оба направления отражают сложную семантику самого слова «жертва», за которым стоят как минимум две реалии. Если в первом случае речь, как правило, идет о топике совершенно определенного рода (упоминание жертвоприношений стало общим местом для обличений и характеристики нехристианского поведения и мировоззрения), то во втором случае дело обстоит сложнее, несмотря на частотность принципа imitatio Christi, описанного Т. Р. Руди в системе агиографической топики [Руди: 62].

Принцип imitatio Christi реализуется в нескольких мотивах: желании полного уподобления Христу, восприятии собственной смерти как уподобления страданиям мучеников Христовых, предсмертном прощении врагов [Руди: 68]. Однако подобный объединительный принцип, будучи доминантным для жанра жития, недостаточен для объяснения взятых в отдельности случаев использования топики imitatio Christi. Не упрощается ли литературный сюжет или индивидуально-авторское стремление при обобщении настолько разнородных фактов?

Крестная смерть Христа вписывается в более общую систему топосов, которую можно охарактеризовать как угодную Богу жертву, и это не только смерть, но и служение, духовная жертва ${ }^{3}$. Чаще всего книжники прибегают к теме жертвы для описания соответствующего подвига, однако даже факт уподобления Христу может по-разному эксплицироваться в архитектонике текста: от буквального повторения подвига (мученичества) и готовности к жертвенной смерти до авторских размышлений или значимого риторического элемента в системе аргументации и т. д. ${ }^{4}$ Случаи обращения к жертвенной смерти Христа, хотя и входят в топику imitatio Christi, могут быть описаны более детальным образом; в то же время необходимо учитывать, что жертва Христа осмысляется в памятниках разной жанровой природы.

Задачей данной работы является исследование особенностей и динамики топики жертвы в публицистических памятниках древнерусской литературы XVI в., когда тема жертвы начинает обсуждаться на принципиально ином уровне, касающемся не только собственно христианской аксиологии, но и мирских 
сфер жизни ${ }^{5}$. Связаны эти процессы с обособленным положением категории жертвы в культуре переходного времени: она в равной степени характерна как для сакральной небесной, так и для мирской земной логики и является своего рода необходимым связующим звеном между ними.

Репрезентативным источником этого времени, имеющим дело с категориями жертвы и жертвенности, являются публицистические сочинения Ивана Грозного и Андрея Курбского, реконструирующие нравственную атмосферу эпохи ${ }^{6}$. Исследователи не раз отмечали, что одной из ключевых тем посланий князя царю стало обвинение его в убийстве невинных людей, впоследствии, по убеждению Курбского, обретших статус новомучеников [Филюшкин: 74]. По сути, автор прибегает к топике imitatio Christi, однако с совершенно иными, чем создатели агиографических произведений, задачами. Этому же подчинена и его «История о великом князе Московском» (1570-е гг.). При всем многообразии исследований сочинений Курбского и Грозного 7 они недостаточно изучены в аспекте собственно поэтики, в то время как в публицистике благодаря эмоциональному напряжению текста осваивались новые возможности жанра, открывались новые грани поэтики и воздействующей силы слова как такового [Лурье: 444-449].

\section{Мученики или изменники: жертвы царя или предатели государства?}

Буквально с первых строк первого послания Ивану Грозному Курбский обвиняет его в неправедных убийствах:

«Про что, царю, сильных в[о Израили побил] еси и воевод, от Бога данных ти на враги твоя, различными смертми разторгнул еси, и победоносную святую кровь их во иеркв $[a] x$ [Божиях пр]олиал еси и мученическими кровьми праги церковныя обагрил $e c u$ и на доброхотных твоих, душа своя за тя полагающих, неслых[ованные от] века муки и смерти и гонениа умыслил еси, изменами и чародействы и иными неподобными облыгаа православных <...>? (здесь и далее курсив мой. - А. П.) .

В этом пассаже тема жертвы заявляется Курбским в двух «перекрестных» направлениях. Первое заключается в обвинении царя в пролитии мученической крови «во церквах 
Божиях», второе раскрывается через фразу «душа своя за тя полагающих», отсылающую к евангельскому «болши сея любве никтоже имать, да кто душу свою положитъ за други своя» (Ин. 15:13). Новомученики, о которых пишет Курбский, были готовы к добровольной жертве - гибели за царя. В гневе Грозный обвинил их в «непотребных» для православного человека злодеяниях, направленных в т. ч. против государя.

Упомянув «сильных во Израили», князь тем самым обвинил царя в истреблении лучших представителей русского народа, истинных православных мучеников, пожертвовавших собой ради Христа. Усиливая обвинения, Курбский включает в аргументацию собственную судьбу, пронизывая текст библейскими аллюзиями и призывая в свидетели чувства («совесть») и разум:

«[<..>И за] благаа моя воздал ми еси злаа и за возлюбление мое - непримирительную ненависть. Кровь моя, яко вода пролита за тя, [вопиет на] тя Богу моему. Богъ - сердцам зритель - во уме моем прилежне смышлях и совесть мою сведетеля представлях, и исках, и зрех [смышленно] обращаася, и не свем себе, и не найдох в чем пред тобою виновата и согрешивша» (ППК: 288).

А. И. Филюшкин в герменевтическом анализе посланий Курбского не учитывает, что князь затрагивает в этом высказывании тему, условно говоря, «жертвы за царя»: «Курбский здесь, с одной стороны, подчеркивает собственную праведность, с другой - сближает ее с жертвенностью праведников во имя Христово и тем самым поступки царя - с деяниями гонителей на христианство» [Филюшкин: 250]. Можно предположить, что Курбский дает своего рода иллюстрацию к процитированному выше фрагменту: он говорит о себе как о человеке, пострадавшем за царя («за тя»), но парадоксальным образом пострадавшем от него же. Сочетание «кровь вопиет к Богу» достаточно устойчиво для древнерусской литературы с начала ее появления ${ }^{9}$ - помимо семантики насильственной смерти, с учетом контекста Книги Бытия, подразумевается кровь Авеля, принесенного в жертву Богу собственным братом: «И рече Господь: что сотворилъ еси сіе? гласъ крове брата 
твоего вопіетъ ко мнъ от земли» (Быт. 4:10) — и, соответственно, связано с идеей Божественного возмездия.

Курбский не только пишет о себе как о потенциальной жертве, но и напоминает царю о своих военных заслугах и ранениях - жертве во благо государя: «...паче же учащаем бых ранами от варварских рук в различных битвах. Сокрушенно же ранами все тело мое имею» (ППК: 288). Он упрекает Грозного, что тому нет дела до его подвигов и страданий: «И тебъ, царю, вся сиа ни во что же бысть» (ППК: 288).

К концу послания Курбский объединит безвинных мучеников с теми, кто «заточен» или «прогнан» Грозным (как и он сам), - все они взывают к Богу и просят об отмщении, помня о «блаженстве» гонимых «правды ради» и имея в виду грех неблагодарности:

«Царю, не помышляй и не мудрствуй мысльми, аки уже погибших [и избиенных] от тебя неповинно, и заточенных, и прогнанных без правды. Не радуйся о сем, аки хваляся сим: разсеченыя тобою у престола [предстоят] Владычня отомщения на тя просят, заточенныя же и прогнанныя тобою без правды от земля Богу вопиют на тя день и нощь!» (ППК: 288).

Жанровая специфика переписки способствует появлению в литературе Древней Руси «голоса жертвы», точки зрения, в которой отчетливо проявляется идеологическая направленность (ср.: [Успенский, 1995: 19-29]). Переписку Ивана Грозного и Андрея Курбского можно рассмотреть посредством сравнения двух противопоставленных по ряду параметров «жертвенных» позиций: и тот, и другой преследуют, в сущности, одни и те же цели: выставить себя жертвой перед противником и доказать, что один пострадал от неправедных действий другого. Задача в обоих случаях осложняется необходимостью не только доказать обратное, но и оспорить аргументацию противника, по причине чего текст преобразуется в скрытый диалог, вбирая в себя разноречивые аргументы.

Пальма первенства в споре принадлежит Курбскому: отталкиваясь от его аргументации, царь будет выстраивать собственную линию доказательств и опровержений. Первое, что делает Курбский, - он противопоставляет осознанное жертвенное поведение (готовность к героической смерти за 
царя и отечество ${ }^{10}$ ) и насильственную мученическую смерть. Причем последняя имеет для Курбского значение не в связи с благодатью, которая ожидает мучеников, а в связи с претерпеванием страданий от нечестивого царя, поскольку никто из них не хотел страдать подобным образом. Курбский в соответствии с мирской логикой отвергает жертву во имя несостоятельной личности государя - в один узел им связывается идеализация царя при проявлении Божественной воли в его поставлении и характеристика самой личности, обладающей или не обладающей качествами достойного монарха.

Князь делает все возможное, чтобы доказать, что Иоанн IV не подлинный христианский царь - на это нацелены бесчисленные риторические приемы (преимущественно «общие места»), к которым он прибегает. Среди них - обличение языческого и шире антихристианского принесения неправедных жертв (общее место, известное на Руси с первых веков христианства).

Для Курбского, как и для большинства православных книжников, использующих этот прием, не стоит вопрос о том, кому язычник приносит жертвы: несомненно, кумиру, идолу, в христианском контексте - дьяволу. Пьянство, гордыня, гнев и прочие грехи также маркируются как «нематериальные» жертвы губителю человечества. Однако Курбский не столько отдает должное риторике, сколько формулирует конкретную оценку.

Одно «темное» место в первом послании имеет непосредственное отношение к рассматриваемой теме:

«...умышляеши на христианский род мучительныя сосуды, па[че же наругаешися] попирающи аггельский образ, согласующим ти ласкателем и товарыщем трапезы, бесогласным твоим бояром и гу[бителем души твоей и] телу, и детьми своими паче ж Кроновых жерцов действуют» (ППК: 288).

Образы «Кроновых жерцов» и «мучительных сосудов» (орудий) равноположены в тексте и призваны усилить обвинения царя и его окружения в нехристианском поведении через сравнение с «еллинскими» богами. Курбский последовательно доказывает, что убитые царем - мученики за веру, 
а сам государь руководим Антихристом в лице злых советников: «...не пригоже таким потакати, о царю!» (ППК: 289). Эта идея будет развита в «Истории» Курбского, где он назовет Грозного «новоявленным звърем»

Прославляя новомучеников, Курбский не может отнести себя к жертвам царя потому, что, в отличие от убитых, он бежал из страны и не претерпел «страсти». Но «точка зрения» жертвы для Курбского сопряжена не только со смертью Курбский помещает себя в один ряд с теми, кого коснулись злодеяния царя, и трактует военные подвиги как страдания, что вызывает ответную иронию Грозного:

«Се бо есть воля Господня - еже, благое творяще, пострадати.

А аще праведен еси и благочестив, про что не изволил еси от мене, строптиваго владыки, страдати и венец жизни наследити?» ${ }^{2}$.

В ответ Курбский сформулирует различие между смертью за праведного царя, у которого «власть от Бога», и смертью по вине и желанию неправедного монарха - последнюю он приравнивает к самоубийству: «Аще ли же кто прелютаго ради гонения не бегает, аки бы сам собе убийца» ${ }^{13}$. Курбский, отрицая измену, оправдывает свое бегство нежеланием совершить смертный грех самоубийства - дерзкая для своего времени мысль по отношению к царю. Для него важно доказать, что он, как и все «сильные во Израили», был готов пострадать за благое дело, - так князь демонстрирует свое соответствие требованиям христианской этики.

Иван Грозный, безусловно, понимал цели посланий Курбского, распознавал их литературную топику. Царю было выгоднее опровергать, иронизировать и издеваться над литературными приемами князя: полемика между царем и его бывшим боярином велась не только на идеологическом, но и на литературном уровне. Для первого послания Грозного характерно намерение опровергнуть аргументацию изменника в специфическом для него «кусательном» стиле ${ }^{14}$.

Грозный стремится вернуть трактовку действий князя к средневековому смирению перед властью, не признавая, что ситуация с самодержавием требует изменения и в поведении монарха. Он «погружает» себя в биографический 
и риторический контекст «православного истиннаго християнского самодержавства, многими владычествы владеющаго» и обличает Курбского как врага христианства: «...крестопреступнику честнаго и животворящаго креста Господня, и губителю хрестиянскому...» (ППГ: 13$)^{15}$.

Государь упрекает Курбского в проявлении гордыни евангельской фразой: «Иже есть высокость в человецех, мерзость пред Богом» (ППГ: 36) (ср.: Лк. 16:15). Помимо этого, царь «переносит» Курбского в язычество, возводящее себе кумиров, и приводит для аргументации обширные цитаты из «Слова на святая просвещения» Григория Богослова (см. об этом: [Переписка Ивана Грозного с Андреем Курбским: 395-396]):

«Подобно еллином иступив ума неистовишеся, бесному подобяся; по своей страсти тленных и изменных человек похваляеш, избирая, яко же еллини своих богов почтоша! <...> Яко же бо еллини неподобно скверных человек боги нарекоша тако и ты неподобно тленных человек мученики нарицаеш, и того ради подобает тебе в праздники мучеников своих резания, и страдания, и плясания, и гудения приносити. Яко же еллини, тако же и тебе подобает; яко же они пострадаша, тако и тебе в праздники мучеников своих подобает страдати!» (ППГ: 36).

В данном контексте Курбский изображен язычником, приносящим жертвы своим идолам, - фактически Грозный сопоставляет с ними православных людей (по Курбскому, новомучеников). И хотя князь причисляет убиенных царем к мученикам вне процесса канонизации, отнесение их к языческим идолам характеризует Грозного как человека, несколько заигравшегося понятиями.

Грозному важно опровергнуть тезис о мученичестве и жертвенности тех, кого он считает изменниками, для этого он прибегает к известному риторическому приему - переадресовывает обвинения, используя основные тезисы Курбского против него. Так, он уверен, что князь, сбежав в чужие земли, сам будет проливать христианскую кровь и осквернять святыни, хотя бы в замыслах, ведомых Богу и государю. Усиливая эффект воздействия на читателя, Грозный использует ритмическую прозу, характерную для ораторских текстов: 
«Аще ти с ними воеватися, тогда ти и церкви разоряти, и иконы попирати и крестиян погубляти; аще и руками где не дерзнеши, но мыслию яда своего смертоноснаго много сия злобы сотвориши» (ППГ: 13).

Если Курбский говорил о собственной готовности пострадать за благое дело, то Грозный обращается к Первому посланию апостола Петра с целью «уличить» Курбского в несоответствии этим идеалам: «Се бо есть воля Господня - еже, благое творяще, пострадати» (ППГ: 14) (ср.: «Лучше бо есть благое творящымъ, аще хощетъ воля Божія, пострадати, нежели зло творящымъ» - 1 Пет. 3:17).

Грозный категорически отрицает нравственные достоинства изменников, переводя мученичество в наказание за преступления:

«Како же не стыдишися злодеев мученики нарицати, не разсуждая, за что кто страждет? Апостолу вопиющу: “Аще кто незаконно мучен будет, сиречь не за веру, не венчается"; божественному убо Златоусту и великому Афонасию во своем исповедании глаголющим: мучими бо суть татие, и разбойницы, и злодеи, и прелюбодеи: такови убо не блажени, понеже грех ради своих мучими бысть, а не Бога ради» (ППГ: 18).

Подрывая аргументацию Курбского, он стремится не только дискредитировать идейную составляющую первого послания, но и обнажить «порочность» литературных приемов противника. Во многом Курбский брал за основу агиографический канон и следовал высокому стилю, наполняя текст сакральными образами и риторикой (особенно ярко это проявится в «Истории»). Грозный стремится разрушить сакральный смысл его текстов и делает это, будучи талантливым книжником, с многочисленными ссылками на Священное Писание. В то же время царь подробно перечисляет обвинения Курбского, дословно его цитирует, но опровергает их едва ли не одним аргументом: «...то еси писал и глаголал лжею, яко же отец твой диявол научил тя есть» (ППГ: 25), - уходя от 
логического рассуждения и характеризуя его высказывания как порождение дьявола.

Кроме того, Грозный воссоздает картину собственных страданий, особенно акцентируя детские переживания (наиболее уязвимую, детскую жертву) и объясняя свое спасение заступом высших сил, включая родовое благословение:

«Се ли разумевая “супротив”, яко вашему злобесному умышлению тогда, Божиею милостию и пречистые Богородицы заступлением, и всех святых молитвами, и родителей своих благословением погубити себя не дал есми?» $(П П Г: 16)^{16}$.

«Кольми же паче наша кровь на вас вопиет к Богу, от вас самех пролитая: не ранами, ниже кровными потоки, но многими поты...» $(\Pi \Pi \Gamma: 42)^{17}$.

Также царь обвиняет изменников в желании убить его сына: «И се ли убо доброхотны есте и души за мя полагаете, еже, подобно Ироду, ссущаго млеко младенца моего смертию пагубною хотесте света сего лишити, чюжаго же царя в царство ввести? Се ли за мя душу полагаете и доброхотствуете?» (ППГ: 25).

Вспоминая царя Ирода, по евангельской легенде погубившего Вифлеемских младенцев с целью убиения Сына Божия, Грозный обвиняет противников в противодействии власти от Бога, стремлении к самозванству (ввести «чюжого царя» вместо законного «от Бога»).

В этом очевидно намерение Грозного выставить себя перед Курбским пострадавшей стороной, входящее в собственно литературные задачи Грозного. В свою очередь Курбский не уступает в этом Грозному по тем же «литературным» причинам. В. В. Калугин отмечает, что «Курбский настолько вжился в литературный образ, что потребовал во втором письме Грозному сострадания к себе» [Калугин: 142]. Исследователь связывает это с возмущением князя в связи с несоблюдением правил эпистолографии (см.: [Калугин: 142-143]). Думается, что у Курбского были и другие причины требовать от Грозного сострадания - это требование было обусловлено осознанием себя пострадавшей стороной.

Во втором послании Курбскому Грозный продолжит тему бесчисленности собственных страданий: «Да много того. Что 
мне от вас бед, всего того не исписати» ${ }^{18}$. В ответ на упреки Курбского в «нечистом» поведении он обвинит своих врагов в том, что его разлучили с женой, отсюда и «Кронова жертва»:

«А и з женою вы меня про что разлучили? Толко бы вы у меня не отняли юницы моея, ино бы Кроновы жертвы не было» (ВПГ: 104).

Царь и сам словно требует сострадания к себе - язык описания собственных страданий через категорию жертвы схож с языком Курбского, несмотря на противоположность позиций. При этом Грозный хорошо понимает, на что намекает противник. Как христианин, царь осознает извечную греховность бренного человека, но стремится по возможности смягчить ее степень и не распространять ее на царский венец: он категорически не согласен со сравнением с языческими царями, по вине которых появлялись мученики за веру.

\section{Жертвенность власти и жертва власти}

Можно согласиться с мнением Д. М. Буланина, что «спор Курбского с Грозным в значительной степени был беспредметным. Оппоненты исходили из одного и того же представления об идеальном самодержце, представления, ориентированного на совокупность византийских и иноземных образцов и примененного для раскрытия новой провиденциальной роли Московского царства. Спор сводился к дебатам о том, насколько Грозный соответствовал в прошлом и в настоящем аксиоматичной для обоих корреспондентов парадигме богоизбранного правителя» [Буланин: 89-90]. В то же время Курбский и Грозный явно добавляют к идеальному образу богоизбранного правителя собственные оценки. Грозный убежден, что царь в своем поведении должен соответствовать времени: «Како убо, по твоему безумному разуму, единако быти царю, а не по настоящему времени?» (ППГ: 18).

В частности, Иван Грозный соответствующим образом сопоставляет церковную власть и царскую, их различие диктует иной тип поведения и не может оцениваться в одном ключе:

«Но ино убо еже свою душу спасти, ино же многими душами и телесы пещися; ино убо есть постническое пребывание, ино 
же во общем житии сожитие, ино же святительская власть, ино царское правление. <...> Се убо разумей разньство постничеству, и общежительству, и святительству, и царству. И аще убо ицарю се прилично: иже биющему в таниту обратити другую?» (ППГ: 24).

Общехристианский постулат о спасении через смирение оказывается несущественным для государя при исполнении им «царского правления». Не подводит ли здесь Грозный к идее о том, что на царя вообще не распространяется необходимость жертвенного смирения и т. п.? ${ }^{19}$

По мнению А. В. Каравашкина, «жертва царя, с точки зрения Грозного, состоит не только в том, что он принимает на себя ответственность за своих подданных и готов расплачиваться за грехи “мира” на Страшном суде, но и в том, что царь вольно или невольно должен нанести ущерб своей душе и, возможно, пожертвовать личным спасением “царствия ради”» [Каравашкин, 2000: 187-188]. Вряд ли можно согласиться с тем, что Грозный видит предназначение царя в смирении и жертве. Необходимо различать активную и пассивную роли (мучителя и жертву), внутренние и внешние проявления жертвы: Грозный убежден, что его окружают враги, и ему предназначено противостоять их угрозам, быть наказующей силой. В своем понимании собственных страданий как жертвенности Грозный несколько удаляется от христианского ее понимания, о чем он говорит сам, когда сопоставляет священство и царство. Если внутренне, в соответствии с небесной логикой, когда речь идет о спасении души, царь готов к жертвенности, то касательно действий правителя царь предпочитает карать, а не смиряться.

Несколько раз Грозный обвиняет изменников, якобы готовых в прошлом пострадать за него, но на деле желавших его смерти или, например, воцарения брата отца (Андрея Старицкого):

«И тако ли душу за нас полагают, еже нас хотели погубити, а дядю нашего воцарити?» (ППГ: 27).

Русский царь формулирует смысл прогосударственного (процарственного) значения готовности пострадать, заявляя 
Курбскому, что в их время нет мучеников за веру и страдания изменников - это наказание за преступление, и иного не дано, при этом он разделяет внешнюю преданность и внутренние убеждения. Лживость внешнего поведения имеет результатом «казнь»:

«...мучеников же в сие время за веру у нас нет ${ }^{20}$; доброхотных же своих и душу за нас полагающих истинно, а не лестно, не языком глаголюще благая, а сердцем злая собирающе, не пред очима собирающе и похваляюще, а вне - расточяюще и укаряюще $<\ldots>$ мы того жалуем своим великим всяким жалованием; а еже обрящется в сопротивных, еже выше рехом, тот по своей вине и казнь приемлет» (ППГ: 26).

Приведенные высказывания государя не соответствуют концепции «мучителя»во имя ияарства, предложенной в работе А. В. Каравашкина и заключающейся в том, что царь хочет поспособствовать через наказание искуплению грехов своих подданных, в т. ч. их «самовольства»: «Богоизбранный государь получает особые права, он не только заботится о чистоте веры, но и должен сдерживать “самовольство”, становясь своеобразным исполнителем казней Божиих и главным защитником высшей справедливости. И здесь дело не в том, что царь должен обуздать чье-либо самоопределение, а в том, что он обязан направить его на стяжание жизни вечной» [Каравашкин, 2000: 182].

Скорее, нужно говорить о том, что царь, будучи волен распоряжаться жизнями своих подданных, предпочитает не только видеть их готовыми пострадать за отечество, но и твердой рукой направить их на это под страхом наказания:

«Се убо, яко же выше рех, сего ради повинныя прияша казнь по своим винам, а не яко же ты лжеши, неподобне изменников и блудников нарицаеши мученикы и их кровь победоносну и святу, и нам супротивных сильными нарицая; и отступников наших воеводами нарицаеш, доброхотство же их и души их полагания за нас...» (ППГ: 34).

Грозный спекулятивно искажает смысл угрозы Курбского о «вопиющей крови» за преступления, выстраивая логику страдания за «отечество» как обязательного долга: 
«И аще кровь твоя, пролитая от иноплеменных за нас, по твоему безумию, вопиет на нас к Богу, и еже убо не от нас пролитая, тем же убо смеху подлежит сия, еже убо от иного пролитая и на иного вопиет, паче же и должная отечеству сие совершил еси; аще бы сего не сотворил еси, то не бы еси был християнин, но варвар; и сие к нам неприлично» (ППГ: 42).

В прогосударственную идеологию Грозного вписывается идея жертвы за царя, за государство, в конечном счете - за христианский «народ». Эта идея имеет глубокие христианские корни и требует от подданного не только верности, но и готовности пострадать «не токмо до крови, но и до смерти»:

«На род же кристиянский мучительных сосудов не умышляем, но паче за них желаем противо всех враг их не токмо до крови, но и до смерти пострадати» (ППГ: 46).

Это высказывание вносит в первое послание идею готовности царя пожертвовать собой. О ней достаточно подробно писал А. В. Каравашкин [Каравашкин, 2000: 183-204], упомянувший о предыстории идеи и ее распространенности в царском окружении. В частности, Вассиан Рыло призывал Ивана III к подвигу в послании на Угру ${ }^{21}$, а в одной из боярских грамот говорится:

«...мы видимъ своего благочестиваго государя во всъх благихъ сіяюща, и милость его къ народу христіанскому такова, не токмо трудомъ и попеченіемъ и промысломъ персоны своея, но гдъ доведетца за православіе и крови своея и главы своея положити не отмещетца....»22.

Иногда Грозный обсуждает в одном и том же контексте мученичество и жертву за отечество, сознательно разделяя два явления и отдавая предпочтение второму. Эта идея Грозного не была новаторской, но изначально имела связь с понятием «Русская земля», корни которого нужно искать в родовом праве. Царь, осознавая или не осознавая, привносит к этому мотиву дополнительный оттенок, что выражается в использовании местоимений: когда царь говорит «душу свою за нас полагают», он не всегда имеет в виду жертву во имя христианского народа или государства - можно предположить, что он имеет в виду самого себя: 
«И тако ли душу свою за нас полагают, еже убо душу нашу желают от мира сего на всяк час во он век препустити?» (ППГ: 29).

Понимание истоков этих идей Грозного требует дополнительных изысканий, но так или иначе можно говорить об очередном этапе формирования новой государственной мифологии ${ }^{23}$. Типологически сходные концепции жертвы царя и жертвы за царя обнаруживаются в Западной Европе эпохи Высокого Средневековья [Канторович: 340-342, 361-362, 370].

$\mathrm{B}$ «Кратком отвещании на зело широкую епистолию князя великого Московского», являющемся своеобразным «литературным манифестом» писателя-западника [Калугин: 64-71], [Лихачев, 1987: 181], будет продолжена линия первого послания: Курбский, уповая на Второе пришествие, верит в свое нахождение рядом со всеми мучениками и утверждает подлинное судилище, даже не действия, а совести:

«...тогда, егда Христос приидет судити, и возглаголют со многим дерзновением со мучащими или обидящими их, иде же, яко и сам веси, не будет лица приятия на суде оном, но кождому человеку правость сердечная и лукавство изъявляемо будет, вместо же свидетелей самаго кождаго свойственно совести вопиющей и свидетельствующей $»^{24}$.

По наблюдению А. И. Филюшкина, во фразе Курбского «смирившемуся уже до зела» присутствует утверждение духовного подвига, превышающего царский: «...князь противопоставляет свое смирение - несомненную добродетель гордыне царя» [Филюшкин: 306]. По сути, речь идет о поиске Курбским в своей биографии духовной жертвенности:

«...ко мне, человеку, смирившемуся уже до зела, в странстве, много оскорбленному и без правды изгнанному, аще и многогрешному, но очи сердечные и язык не неученный имущу...» (ВПК: 101).

В третьем послании Грозному Курбский напишет в ответ на обвинения в измене и клятвопреступлении:

«А еже пишеши, имянующе нас изменники, для того, иже есмя принужденны были от тебя по неволе крест целовати <...> аще кто по неволе присягает или кленется, не тому бывает грех, 
кто крест целует, но паче тому, кто принуждает, аще бы и гонения не было» (ТПК: 108).

А. И. Филюшкин обращает внимание на семантику процедуры присяги, крестоцелования: «При клятве на кресте проявлялась и другая его семантика - соединение в данном символе высшего с низшим, жизни и смерти. Для православного человека решающее значение в данной клятве имело то, что крест - это символ мук Спасителя, искупившего ими человечество от греха. Тем самым, нарушая столь важную клятву, клятвопреступник предавал искупительную жертву Иисуса» [Филюшкин: 400]. В послании дискредитируется ритуал крестоцелования, носящего недобровольный характер.

B XVI в. рассуждения о присяге были довольно частыми, во многом «сформировалось представление о том, что, целуя крест государю, подданные “отдают” ему свои “души”: государь отвечает за их спасение, а измена царю “губит душу” человека» (см.: [Курбский: 639]). В «Истории» Курбский говорит об опричниках как о связавших себя клятвой гонителях христиан:

«Кто слыхал от въка таковые, иже Христовым знамением кленущесь на том, да Христос гоним будет и мучим? И на том крестьное знамение целовати, да церковь Христова растерзаетца различными муками?» (ИК: 184).

Для Курбского, как и для многих его современников, оказывается важной архетипическая идея жертвенности царя в борьбе с врагами:

«И аще погибают царие или властели, яже созидают трудные декреты и неудобь подъемлемые номоканоны, кольми паче не токмо созидающе неудобь подъемлемые повеления или уставы з домы погибнути должны. Но во яковых сии обрящутся, яже пустошат землю свою и губят подручных всеродне, ни сосущих младенцов не щадяще, за них же должни суть властели, кождый за подручных своих, кровь свою против врагов изливати...» (ТПК: 117).

Однако Курбский намекает здесь и на то, что царь должен ответить за то, что погубил такое число людей, являющихся христианами, а не врагами. В определенном смысле князь проводит здесь идею расплаты царя жизнью за грехи. В том 
же третьем послании Курбский вспоминает историю взятия Иерихона Иисусом Навином и вполне недвусмысленно по отношению к Грозному приводит пример Ахара (Ахана), нарушившего запрет: «...единаго же ради греха Ахарова, егда Господь прогневался на весь Израиль...» (ТПК: 114) - за грехи царя, по мнению Курбского, страдает весь русский народ. С той же мыслью он вспоминает наказание Израиля за грехи детей священника Илия.

\section{Обличение царя и прославление новомучеников}

Глубокое убеждение Курбского в высказываемых в посланиях царю мыслях подтверждается их развитием в объемном сочинении «История о делах великого князя московского». Здесь автор продолжает тему мучений целого народа:

«...мучити повелЂл оных, ни единаго, ни дву, но народ цзпл. Их же имян, тъх неповинных, яже в тъх муках помроша, множества ради исписати невозможно» (ИК: 136).

В «Истории», как и в третьем послании, Курбский характеризует род царя как «издавна кровопивственный» (ТПК: 109), а также формулирует концепцию «двух Иванов» (благочестивого и "развращенного»), показывая не только свое, но и всеобщее удивление перед катастрофической переменой:

«Зело аз о сем удивляюся и все сущие, имущие разум, наипаче же те, которые пред тем знали тя, когда в заповедех Господних пребывал еси <...>. А ныне во якую бездну глупства и безумия развращения ради прискверных маньяков твоих совлечен еси и памяти здравы лишен!» (ТПК: 113).

Курбский будет неоднократно призывать Грозного возвратиться к прежнему образу через покаяние и «разум»:

«Помяни первые дни и возвратися. Поки нагою главою безстудствуешь сопротив Господа твоего? Або еще не час образумитися и покаятися, и возвратитися ко Христу?» (ТПК: 115).

Части «Истории», подчиненные разнородным задачам, ориентируются на разные жанры ${ }^{25}$ : хронику, историю (как рассказ о прошлом), мартирий, поучение, биографию, мемуары, однако очевидна цельность этого памятника, обусловленная целью 
создания (см.: [Ерусалимский, 2015]). Если первая часть «Истории» в основном посвящена «первому» Ивану, то вторая часть озаглавлена Курбским как «История новоизбиенных мучеников». Он обращается здесь к популярному в западноевропейской агиографии жанру мученического жития и создает своеобразный мартиролог [Калугин: 182-204].

Курбский использует словесные формулы, характерные для житийной литературы о мучениках: «...яко агнцы неповинно заколены еще в самом наусии» (ИК: 22); «...усечению главы своея святые» (ИК: 142); «...сего ради приими души наши в живодателные руце твои, Господи», «смерть вкусил от мучителя неповинне» (ИК: 158); «Его ж измлада возлюбил, за Него ж и на старость пострадал» (ИК: 178).

Помимо того что Курбский создает своеобразный мартиролог, он пишет своего рода «антижитие» (термин Д. С. Лихачева) Ивана Грозного, и оба эти приема работают на создание образа неправедного правителя. Курбский стремится не только вызвать жалость к жертвам и прославить новомучеников, но и обличить злодеяния царя, поэтому он сравнивает Грозного с «древними мучителями» - Иродом, Фокой, Нероном и др. На страницах «Истории» представлено бесчисленное множество мученических смертей. И если в их создании и участвуют те или иные агиографические топосы, то не потому, что автор пишет множество житий одновременно, а потому, что они отвечают оценке злодеяний царя.

Как автор Курбский берет на себя функцию судьи и подводит к идее о Страшном суде, на котором он будет очевидцем, а его «История» станет важным свидетельством, поскольку в ней перечислены многие грехи Грозного и обозначены его жертвы.

Эсхатологические настроения Курбского были присущи и его раннему творчеству ${ }^{26}$, однако с наибольшей силой они выразились в «Истории» и других его поздних трудах (например, в предисловии к переводу из Иоанна Златоуста - «Новому Маргариту»). В. В. Калугин считает, что Курбский, планировавший перевести некоторые труды Иоанна Дамаскина, заимствовал из «Богословия» образ царя-мучителя, развивающийся «в соответствии с эсхатологическим учением о приходе 
в мир Антихриста», и «неповиновение Грозному принимало характер священной войны с Антихристом» [Калугин: 177-178].

Пафос сочинения Курбского определяется по-разному. Сам автор называет рассказ о мучениках трагедией: «...прегорчайшие тое и жалостные ко слышанию трагедии», - снабдив это место греческой глоссой: «Трагедия сиръчъ игра плачевная, яже радостию начинаеться и зъло многими бедами и скорбми скончеваеться» (ИК: 148).

А. В. Каравашкин уточняет, что «состояние мученичества воспринимается Курбским не столько радостно, просветленно, с упованием на торжество правды, сколько мрачно, с надрывом и проклятиями. Подвиг мученика здесь трагичен, лишен того жизнеутверждающего пафоса, который он зачастую приобретал в средневековой литературе» [Каравашкин, 2000: 332]. В то же время трагедийность жертвы и мученичества для Курбского как ортодоксального православного книжника явно не конечна. Курбский прославляет новомучеников, очутившихся в раю:

«О, преблаженнии и достохвальные святые мученики, новоизбиенные от внутренняго змия! За добрую совесть вашу пострадаете, и мало здъ претерпъвше и очистившеся прехвалным сим крещением, чисти к пречистейшему Христу одоидосте мзду трудов своих восприяти!» (ИК: 216).

Конечно, Курбский не склонен изображать целиком смиренное принятие смерти, и это отразилось на мрачной атмосфере «Истории» и посланий Грозному: Курбский постоянно говорит об отмщении и предсказывает наказание царя на Страшном суде. Но в то же время он акцентирует святость новомучеников и их блаженство в раю. Пафос посланий Курбского царю и «Истории» заключается в надежде, что жертвы окажутся ненапрасными тогда, когда Грозного будет судить Господь, и Курбский в этом практически не сомневается ${ }^{27}$.

Грозный выступает принципиально против такого учительства: «Почто ж и учитель ми еси, душе моей и телу моему? Кто убо тя постави судию или владателя надо мною?» (ППГ: 19). Не лишним будет напомнить, что Грозный обличал Курбского и за то, что тот считал, что будет участвовать в спасении мира рядом с Господом: 
«И много слепотствующия ради твоея злобы не можеши истинны ведети: како мняй стояти у престола владычня и повсегда со аггелы служити, и своими руками агнеи жремый закалати за мирское спасение сподобися, и сия вся поправшым вам с своими злобесовскими советники, на нас же своими злолукавыми умышлении многая томления подвигосте?» (ППГ: 15).

В определенной степени Курбский считает себя жертвой наравне с другими мучениками. Это удалось проследить на примере переписки с Грозным и «Истории» - памятнике, обладающем элементами автожития [Васильев: 128-131]. Курбский возводит себя в ранг мученика не столько для того, чтобы вызвать к себе жалость как к жертве, сколько в целях нравственно уничтожить противника. Он не готов смиренно простить Грозного и, погружая себя в мученический контекст, своими сочинениями преодолевает молчание жертвы и невозможность сопротивляться.

В. К. Васильев отмечает сложность ореола святости в XVI в., когда «в русской культуре оформляется и неофициальная точка зрения на святость. Не русская церковь канонизирует убиенных мучеников, и не мирские власти добиваются признания чьей-либо святости, а вне и вопреки позиции государственной власти святыми признаются пострадавшие от нее» [Васильев: 143]. Думается, дело не столько в оформлении неофициальной точки зрения на святость, сколько в меняющемся отношении к сакральным христианским категориям как таковым: обсуждение их выходит на другой уровень, не остаются в стороне от этого Иван Грозный и другие книжники XVI в.

Так, в «Житии митрополита Филиппа» герой говорит царю: «О царю! Мы убо приносимъ жертву Господеви, а за олтаремъ неповинно льется кровь християнская, и напрасно умираютъ» ${ }^{28}$. М. М. Кром упоминает утешительное послание старца Иосифо-Волоколамского монастыря Фотия вдове убитого Грозным князя Ивана Ивановича Кубенского: «Господь Бог благоволением своим и человеколюбием своим государя князя Ивана аще и горкою смертию скончял, но кровию мученическою вся грехи его омыл...» (цит. по: [Кром: 318]).

Важен в связи с этим вывод В. В. Калугина, который во многом еще только предстоит иллюстрировать при более 
точечном анализе творчества Курбского: «Под его пером наметилось превращение жития в историко-биографическое повествование, прославляющее мучеников не столько религиозной, сколько политической идеи» [Калугин: 204].

В сочинениях Курбского и Грозного наблюдается причудливое сочетание старых и новых приемов топики, когда «общие места» древнерусской книжности начинают использоваться в идеологических целях. Вряд ли приходится иметь дело с искажением понимания жертвенного подвига, однако обоих авторов объединяет субъективность в обращении с категорией жертвы.

Можно предположить, что иное, по сравнению с предшествующими эпохами, использование категории было связано с общим для XVI в. подъемом гуманистической мысли. А. И. Клибанов так скажет об этом явлении: «Духовная история русского общества, выдвинув еще в первой половине XVI в. проблему самоценности человека, страстно дебатировавшуюся представителями всех общественных кругов, ее сторонниками и противниками, опережала ход социальноэкономического развития страны» [Клибанов: 278].

И Грозный, и Курбский обращаются в своем творчестве к проблеме ответственности личности, в понимании действий, мыслей и чувств которой не последнее место они отводят категории жертвы не как сугубо религиозному конструкту и даже не как напоминанию о жертве Христа, а как тому, что может случиться в конкретный момент с каждым конкретным человеком. Земная и небесная логика вступают в некоторое противоречие. Курбский нередко обращается к предательству Грозного в земном мире, однако предпочитает использовать религиозную логику ответственности личности за грехи. Царь, как правило, дает собственную «камеру обскура», возвращая читателя к воле Бога, без которой ничего не происходит, а главный исполнитель воли - он сам, однако в этом также проявляется спекулятивная мирская логика Грозного.

Действительно, сочинения Ивана Грозного и Андрея Курбского вступают в область «конфликта интерпретаций» [Каравашкин, 2020]. Жертва для Курбского всегда достойна жалости, это трагедия, но ему не чужда тема искупления и надежда на 
спасение. Автор использует образ жертвы для аргументации и усиления читательского эффекта, при этом в «Истории», помимо оценок и риторики, есть сюжет, и топика жертвы влияет на его развитие. Курбский не намерен находиться на положении безвольной жертвы, по его мнению, это гибельно и равно самоубийству. Риторика в его случае нормативна, он следует книжному канону, но оценка в проанализированных сочинениях подчиняет себя риторику. Так, она подчиняет себе топику жертвы, привнося в нее малораспространенное в древнерусской литературе до этого времени применение к характеристике царя-мучителя и его жертв.

Курбский признает страдания во имя отечества, однако не смешивает их с террором. Грозный, опровергая его аргументацию, по-своему интерпретирует необходимость жертвовать во имя государства, если не профанируя идею жертвы за отечество, то сильно подрывая ее сакральный контекст тем, что невольно переводит высокую идею на политико-идеологический уровень. Царь находит оправдание террору против «изменников» и для их уничижения использует все доступные ему литературные приемы, опровергая аргументы Курбского и оборачивая его обвинения против него.

Авторы создают подчеркнуто публицистические произведения, приспосабливая поэтику предшествующей литературы Древней Руси под свои цели. В их творчестве категории жертвы и жертвенности приближаются к свободе толкования: их использование в конце XVI в. становится возможным во все большем числе контекстов и для все большего числа нужд, не в последнюю очередь, литературных. 


\title{
Список сокращений
}

\author{
БЛДР - Библиотека литературы Древней Руси \\ СККДР - Словарь книжников и книжности Древней Руси \\ ТОДРЛ - Труды Отдела древнерусской литературы
}

\section{Примечания}

* Исследование выполнено при финансовой поддержке гранта Российского научного фонда (проект № 19-18-00186 “"Культура духа” vs “Культура разума”: интеллектуалы и власть в Британии и России в эпоху перемен (XVII-XVIII вв.)»).

1 Вербализацию этих категорий можно проследить, начиная с ранних памятников древнерусской письменности, однако датировать представления о жертве вряд ли возможно: настолько глубокие корни они имеют как в общечеловеческой, так и в славянской культуре.

2 Гораздо менее разработанным аспектом в исследованиях, посвященных жертве и жертвенности в культуре, остается функционирование этих категорий и связанных с ними тем, мотивов, «общих мест», понятий и т. п.: до сих пор наука не располагает более или менее целостной картиной представлений человека того времени. Картина эта может быть сложена из частей целого, категорий, подобно предложенной Д. С. Лихачевым концептосфере [Лихачев, 1997], и в то же время, несмотря на присущую ей целостность, эту картину следует рассматривать, учитывая внутреннюю динамику и движение на оси времени.

3 Ср.: «Молю убо васъ, братіе, щедротами Божіими, представите тълеса ваша жертву живу, святу, благоугодну богови, словесное служеніе ваше» (Рим. 12:1).

4 Проследить неоднозначность такого выделения топики можно и на уровне словесных формул: библейский текст может цитироваться выборочно, книжник также волен отсылать читателя к разным событиям из жизни Христа и мучеников.

5 Достаточно сравнить с ситуацией Нового и Новейшего времени, когда понятие и идея жертвы охватили самые разнообразные сферы жизни человека.

6 Идеологическая атмосфера террора второй половины XVI в. становилась предметом осмысления в работах Р. Г. Скрынникова [Скрынников], И. Мадарьяги [Madariaga], Ч. Гальперина [Halperin].

7 Подробный обзор представлен в словарных статьях: [Лурье, Роменская], [Гладкий, Цеханович], [СККДР: 182-192, 236-246].

8 Первое послание Курбского Ивану Грозному в сборнике конца XVI начала XVII века / подгот. Б. Н. Морозов // Археографический ежегодник за 1986 год / отв. ред. С. О. Шмидт. М.: Наука, 1987. С. 287. Далее ссылки на это издание приводятся в тексте статьи с использованием сокращения ППК и указанием страницы в круглых скобках. 
9 В памятниках Борисоглебского цикла (XI-XII вв.) этими словами Ярослав на поле битвы со Святополком призывает месть Бога.

10 Явление, которое было широко распространено в воинской среде. Курбский при этом был полководцем и говорил совсем не о гипотетическом страдании.

11 Курбский А. М. История о делах великого князя московского / изд. подгот. К. Ю. Ерусалимский. М.: Наука, 2015. С. 136. Далее ссылки на это издание приводятся в тексте статьи с использованием сокращения ИК и указанием страницы в круглых скобках.

12 Первое послание Ивана Грозного Курбскому // Переписка Ивана Грозного с Андреем Курбским / текст подгот. Я. С. Лурье и Ю. Д. Рыков. М.: Наука, 1981. С. 14. Далее ссылки на это издание приводятся в тексте статьи с использованием сокращения ППГ и указанием страницы в круглых скобках. Грозный дважды повторит эту мысль, в другом варианте она выглядит так: «Аще праведен и благочестив еси, по твоему глаголу, почто убоялся еси неповинныя смерти, еже несть смерть, но приобретение?» (ППГ: 14).

13 Третье послание Курбского Ивану Грозному // Переписка Ивана Грозного с Андреем Курбским / текст подгот. Я. С. Лурье и Ю. Д. Рыков. М.: Наука, 1981. С. 108. Далее ссылки на это издание приводятся в тексте статьи с использованием сокращения ТПК и указанием страницы в круглых скобках.

14 О литературном стиле Грозного см. подробнее: [Шмидт], [Калугин: 225-235], [Лихачев, 1981: 183-202].

15 Это же происходит и далее по тексту. См.: (ППГ: 24-25).

16 Ср. схожие формулировки в Послании и далее: «И якова они бо от бесов пострадаша, таковая аз же от вас пострадах» (ППГ: 17) (о Курбском, Сильвестре и Адашаве); «но в будущем веце хощу суд прияти, елико от него пострадах душевне и телесне» (ППГ: 33) (об Адашеве).

17 Комментаторы отмечают, что «ссылка на “слезы” и “поты” как на жертву, не менее дорогую, чем кровь, заимствована царем из "Просветителя" Иосифа Волоцкого» [Переписка Ивана Грозного и Андрея Курбского: 400].

18 Второе послание Ивана Грозного Курбскому // Переписка Ивана Грозного с Андреем Курбским / текст подгот. Я. С. Лурье и Ю. Д. Рыков. М.: Наука, 1981. С. 104. Далее ссылки на это издание приводятся в тексте статьи с использованием сокращения ВПГ и указанием страницы в круглых скобках.

19 О царской харизме, поведении Ивана Грозного и осмыслении им собственной личности существует обширная литература: [Hunt], [Успенский, 1998].

20 Об этом же царь говорит выше: «Победоносные же святыя крови в своей земле в нынечнее время ничьея явленно, не вемы» (ППГ: 26).

21 Послание на Угру Вассиана Рыло / текст подгот. В. И. Ванеева, пер. О. П. Лихачевой, комм. Я. С. Лурье // БЛДР. СПб.: Наука, 1999. Т. 7. C. 386-399. 
22 См.: [Каравашкин, 2000: 281-282]. Текст выверен по изданию: Сборник Императорского русского исторического общества. СПб.: [Б. и.], 1892. Т. 71. Стлб. 111.

23 Уже в XVIII в. жертва во имя отечества - вполне распространенный языковой штамп, и государственная идея сохраняется едва ли не до XXI в.

24 Второе послание Курбского Ивану Грозному // Переписка Ивана Грозного с Андреем Курбским / текст подгот. Я. С. Лурье и Ю. Д. Рыков. М.: Наука, 1981. С. 102. Далее ссылки на это издание приводятся в тексте статьи с использованием сокращения ВПК и указанием страницы в круглых скобках.

$25 \mathrm{У}$ исследователей нет единого мнения о жанре этого памятника, между тем большинство из них приходит к мнению о его полижанровой природе [Уваров], [Лихачев, 1981: 207-211], [Калугин: 204], [Ерусалимский, 2009: 296].

26 Имеется в виду, например, переписка Курбского со старцем Вассианом Муромским (см.: [Калугин: 23-30]).

27 Не сомневался в этом, по-видимому, к концу жизни и сам Грозный [Булычев: 17].

28 Житие митрополита Филиппа / подгот. текста, пер. и комм. И. А. Лобаковой // БЛДР. СПб.: Наука, 2005. Т. 13. С. 726.

\section{Список литературы}

1. Аверинцев С. С. Риторика как подход к обобщению действительности // Аверинцев С. С. Риторика и истоки европейской литературной традиции. - М.: Школа «Языки русской культуры», 1996. - С. 158-190.

2. Буланин Д. М. Политическая доктрина в афоризмах: малоизученные источники Первого послания Ивана Грозного Андрею Курбскому // Die Welt der Slaven. - 2019. - Bd. 64. - Heft 1. - S. 87-107.

3. Булычев А. А. Между святыми и демонами: заметки о посмертной судьбе опальных царя Ивана Грозного. - М.: Знак, 2005. - 304 с.

4. Васильев В. К. Сюжетная типология русской литературы XI-XX веков (Архетипы русской культуры). От Средневековья к Новому времени. Красноярск: ИПК СФУ, 2009. - 260 с.

5. Гладкий А. И., Цеханович А. А. Курбский Андрей Михайлович // СККДР. - Л.: Наука, 1988. - Вып. 2. Вторая половина XIV - XVI в. Ч. 1. - С. 494-503.

6. Ерусалимский К. Ю. Сборник Курбского. Исследование книжной культуры: в 2 т. / отв. ред. С. О. Шмидт. - М.: Знак, 2009. - Т. 1. - 882 с.

7. Ерусалимский К. Ю. Назначение «Истории» // Курбский А. М. История о делах великого князя московского / изд. подг. К. Ю. Ерусалимский. М.: Наука, 2015. - С. 221-287.

8. Калугин В. В. Андрей Курбский и Иван Грозный: теоретические взгляды и литературная техника древнерусского писателя. - М.: Языки русской культуры, 1998. - 416 с. 
9. Канторович Э. Х. Два тела короля. Исследование по средневековой политической теологии. - 2-е изд., испр. / пер. с англ. М. А. Бойцова и А. Ю. Серегиной. - М.: Изд-во Ин-та Гайдара, 2015. — 752 с.

10. Каравашкин А. В. Русская средневековая публицистика: Иван Пересветов, Иван Грозный, Андрей Курбский. - М.: Прометей, 2000. - 418 с.

11. Каравашкин А. В. Иван Грозный и Андрей Курбский: конфликт интерпретаций // Studia Litterarum. — 2020. - T. 5. — № 1. - C. 148-161. DOI: $10.22455 / 2500-4247-2020-5-1-148-161$

12. Клибанов А. И. Духовная культура средневековой Руси. - М.: Аспект Пресс, 1996. - 368 с.

13. Кром М. М. «Вдовствующее царство»: политический кризис в России 30-40-х годов XVI века. - М.: НЛО, 2010. - 872 с.

14. Курбский А. М. История о делах великого князя московского / изд. подг. К. Ю. Ерусалимский. - М.: Наука, 2015. - 942 с.

15. Лихачев Д. С. Стиль произведений Грозного и стиль произведений Курбского (царь и «государев изменник») // Переписка Ивана Грозного с Андреем Курбским / текст подгот. Я. С. Лурье и Ю. Д. Рыков. - М.: Наука, 1981. - С. 183-213.

16. Лихачев Д. С. На пути к новому литературному сознанию (вторая половина XVI века) // Лихачев Д. С. Великий путь: Становление русской литературы XI-XVII вв. - М.: Современник, 1987. - С. 174-184.

17. Лихачев Д. С. Концептосфера русского языка // Русская словесность: от теории словесности к структуре текста: антология / под общ. ред. В. П. Нерознака. - М.: Academia, 1997. - С. 280-287.

18. Лурье Я. С. Судьба беллетристики в XVI в. // Истоки русской беллетристики: возникновение жанров сюжетного повествования в древнерусской литературе. - Л.: Наука, 1970. - С. 387-449.

19. Лурье Я. С., Роменская О. Я. Иван IV Васильевич Грозный // СККДР. - Л.: Наука, 1988. - Вып. 2. Вторая половина XIV-XVI в. - Ч. 1. - С. 371-384.

20. Переписка Ивана Грозного с Андреем Курбским / текст подгот. Я. С. Лурье и Ю. Д. Рыков. - М.: Наука, 1981. - 430 с.

21. Попович А. И. Жертва «живая» и «мертвая»: топос и разноречие контекста в книжности Древней Руси XI-XIV веков // Летняя школа по русской литературе. - 2019. - Т. 15. - № 2-3. - С. 115-135. DOI: 10.26172/2587-8190-2019-15-2-3-115-135

22. Руди Т. Р. Топика русских житий (вопросы типологии) // Русская агиография. Исследования. Публикации. Полемика / под ред. С. А. Семячко и Т. Р. Руди. - СПб.: Дмитрий Буланин, 2005. - Т. 1. - С. 59-101.

23. СККДР. - СПб.: Дмитрий Буланин, 2012. - Вып. 2. Вторая половина XIV-XVI в. - Ч. 3. - 768 c.

24. Скрынников Р. Г. Царство террора. - СПб.: Наука, 1992. - 576 с.

25. Уваров К. А. Князь А. М. Курбский - писатель («История о великом князе Московском»): автореф. дис. ... канд. филол. наук. - М.: [Б. и.], 1973. $-25 \mathrm{c}$. 
26. Успенский Б. А. Поэтика композиции // Успенский Б. А. Семиотика искусства. - М.: Школа «Языки русской культуры», 1995. - С. 9-218.

27. Успенский Б. А. Царь и патриарх: харизма власти в России (византийская модель и ее русское переосмысление). - М.: Школа «Языки русской культуры», 1998. - 680 с.

28. Филюшкин А. И. Андрей Михайлович Курбский: просопографическое исследование и герменевтический комментарий к посланиям Андрея Курбского Ивану Грозному. - СПб.: Изд-во СПбГУ, 2007. - 624 с.

29. Шмидт С. О. Заметки о языке посланий Ивана Грозного // ТОДРЛ. М.; Л.: Изд-во Акад. наук СССР, 1958. - Т. 14. - С. 256-265.

30. Halperin Ch. J. Ivan the Terrible: Free to Reward and Free to Punish. Pittsburgh: University of Pittsburgh Press, 2019. - 360 p.

31. Hunt P. Ivan IV's Personal Mythology of Kingship // Slavic Review. - 1993. Vol. 52. - Iss. 4. - Pp. 769-811.

32. Madariaga I. Ivan the Terrible. First Tsar of Russia. - Yale: Yale University Press, 2006. $-526 \mathrm{p}$. 
Alexey I. Popovich

Ural Federal University

(Yekaterinburg, Russian Federation)

alexeypopowich@mail.ru

\section{"Playing the Victim": the Pathos of Denunciation and Martyrdom in the Works of Ivan the Terrible and Andrey Kurbsky}

Acknowledgments. This work is supported by the Russian Science Foundation (grant number 19-18-00186).

Abstract. The article explores changes in the use of the categories of victim and sacrifice in political literary artefacts in the second half of the 16th century: namely, the correspondence between Ivan the Terrible and Andrey Kurbsky and Kurbsky's History of the Grand Prince of Moscow. The study shows that the writers of this time used the literary topoi of victim in a fundamentally different way to earlier authors in medieval Russia. The article defines the main means of poetics and rhetoric in the works of Ivan the Terrible and Andrey Kurbsky. The methods for updating the topoi of victim for both authors are similar. Each of them desacralizes a high Christian idea and uses it and a topos for subjective and, as a rule, ideological purposes. Such changes are possible due to the mixing of earthly (profane) and heavenly (sacred) logic when dealing with the categories of victim and sacrifice, which is typical for this time. If, for Kurbsky, the people killed by the tsar are new martyrs, then for Ivan the Terrible, they are justly punished traitors. The tsar believes that subjects should be ready to sacrifice their lives for him. Kurbsky does not deny the necessity of willingness to sacrifice, but he consistently proves that the tsar's personality does not correspond to Christian ideas about the ideal monarch, so he convinces the reader of the possibility of confronting the tsar. At the same time, both authors characterize themselves as a person affected by the actions of the other and use the literary topoi of victim.

Keywords: victim, sacrifice, topoi of victim, correspondence between Ivan the Terrible and Andrey Kurbsky, History of the Grand Prince of Moscow, second half of the 16th century

About the author: Popovich Alexey I. - Laboratory Researcher, Laboratory for the Study of Primary Sources, Ural Federal University (ul. Mira 19, Yekaterinburg, 620002, Russian Federation)

Received: May 4, 2020

Date of publication: October 30, 2020

For citation: Popovich A. I. "Playing the Victim": the Pathos of Denunciation and Martyrdom in the Works of Ivan the Terrible and Andrey Kurbsky. In: Problemy istoricheskoy poetiki [The Problems of Historical Poetics], 2020, vol. 18, no. 4, pp. 67-98. DOI: 10.15393/j9.art.2020.8743 (In Russ.) 


\section{References}

1. Averintsev S. S. Rhetoric as an Approach to the Generalization of Reality. In: Averintsev S. S. Ritorika $i$ istoki evropeyskoy literaturnoy traditsii [Averintsev S. S. Rhetoric and the Origins of the European Literary Tradition]. Moscow, School “Languages of Russian Culture” Publ., 1996, pp. 158-190. (In Russ.)

2. Bulanin D. M. Political Doctrine in Aphorisms: Little-Known Sources of the First Epistle of Ivan the Terrible to Andrey Kurbsky. In: Die Welt der Slaven [The World of the Slaves], 2019, vol. 64, issue 1, pp. 87-107. (In Russ.)

3. Bulychev A. A. Mezhdu svyatymi i demonami: zametki o posmertnoy sud'be opal'nykh tsarya Ivana Groznogo [Between Saints and Demons: Notes on the Posthumous Fate of the Disgraced Tsar Ivan the Terrible]. Moscow, Znak Publ., 2005. 304 p. (In Russ.)

4. Vasil'ev V. K. Syuzhetnaya tipologiya russkoy literatury XI-XX vekov: (Arkhetipy russkoy kul'tury). Ot Srednevekov'ya $k$ Novomu vremeni [The Plot Typology of Russian Literature of the 11th-20th Centuries: (Archetypes of Russian Culture). From the Middle Ages to the New Age]. Krasnoyarsk, Institute of Professional Development of the Siberian Federal University Publ., 2009. 260 p. (In Russ.)

5. Gladkiy A. I., Tsekhanovich A. A. Kurbsky Andrey Mikhailovich. In: Slovar' knizhnikov i knizhnosti Drevney Rusi [The Dictionary of Scribes and Booklore of Ancient Russia]. Leningrad, Nauka Publ., 1988, issue 2, part 1, pp. 494-503. (In Russ.)

6. Erusalimskiy K. Yu. Sbornik Kurbskogo. Issledovanie knizhnoy kul'tury: $v 2$ tomakh [Collection of Kurbsky. The Study of Book Culture: in 2 Vols]. Moscow, Znak Publ., 2009, vol. 1. 882 p. (In Russ.)

7. Erusalimskiy K. Yu. Purpose of the "History". In: Kurbskiy A. M. Istoriya o delakh velikogo knyazhestva moskovskogo [Kurbsky A. M. History of the Affairs of the Grand Prince of Moscow]. Moscow, Nauka Publ., 2015, pp. 221287. (In Russ.)

8. Kalugin V. V. Andrey Kurbskiy i Ivan Groznyy: teoreticheskie vzglyady i literaturnaya tekhnika drevnerusskogo pisatelya [Andrey Kurbsky and Ivan the Terrible: Theoretical Views and the Literary Technique of an Old Russian Writer]. Moscow, Yazyki russkoy kul'tury Publ., 1998. 416 p. (In Russ.)

9. Kantorowicz E. Kh. Dva tela korolya. Issledovanie po srednevekovoy politicheskoy teologii [Two Bodies of the King. A Study on Medieval Political Theology]. Moscow, The Gaidar Institute Publ., 2015. 752 p. (In Russ.)

10. Karavashkin A. V. Russkaya srednevekovaya publitsistika: Ivan Peresvetov, Ivan Groznyy, Andrey Kurbskiy [Russian Medieval Publicism: Ivan Peresvetov, Ivan the Terrible, Andrey Kurbsky]. Moscow, Prometey Publ., 2000. 418 p. (In Russ.)

11. Karavashkin A. V. Ivan the Terrible and Andrey Kurbsky: A Conflict of Interpretations. In: Studia Litterarum, 2020, vol. 5, no. 1, pp. 148-161. DOI: 10.22455/2500-4247-2020-5-1-148-161 (In Russ.) 
12. Klibanov A. I. Dukhovnaya kul'tura srednevekovoy Rusi [The Spiritual Culture of Medieval Russia]. Moscow, Aspekt Press Publ., 1996. 368 p. (In Russ.)

13. Krom M. M. «Vdovstvuyushchee tsarstvo»: politicheskiy krizis v Rossii 30-40-kh godov XVI veka ["The Dowager Kingdom": The Political Crisis in Russia of the 30s - 40s of the 16th Century]. Moscow, Novoe literaturnoe obozrenie Publ., 2010. 872 p. (In Russ.)

14. Kurbskiy A. M. Istoriya o delakh velikogo knyazya moskovskogo [History of the Affairs of the Grand Prince of Moscow]. Moscow, Nauka Publ., 2015. 942 p. (In Russ.)

15. Likhachev D. S. The Style of Grozny's Works and the Style of Kurbsky's Works (Tsar and "Sovereign Traitor"). In: Perepiska Ivana Groznogo s Andreem Kurbskim [Correspondence of Ivan the Terrible with Andrey Kurbsky]. Moscow, Nauka Publ., 1981, pp. 183-213. (In Russ.)

16. Likhachev D. S. On the Way to a New Literary Consciousness (Second Half of the 16th Century). In: Likhachev D. S. Velikiy put': stanovlenie russkoy literatury XI-XVII vv. [Likhachev D. S. The Great Way: The Formation of Russian Literature of the 11th-17th Centuries]. Moscow, Sovremennik Publ., 1987, pp. 174-184. (In Russ.)

17. Likhachev D. S. The Conceptosphere of the Russian Language. In: Russkaya slovesnost': ot teorii slovesnosti $k$ strukture teksta: Antologiya [Russian Literature: from the Theory of Literature to the Structure of the Text: Anthology]. Moscow, Academia Publ., 1997, pp. 280-287. (In Russ.)

18. Lur'e Ya. S. Fate of Fiction in the 16th Century. In: Istoki russkoy belletristiki: vozniknovenie zhanrov syuzhetnogo povestvovaniya $v$ drevnerusskoy literature [The Origins of Russian Fiction: The Emergence of Genres of Storytelling in Old Russian Literature]. Leningrad, Nauka Publ., 1970, pp. 387-449. (In Russ.)

19. Lur'e Ya. S., Romenskaya O. Ya. Ivan IV, Ivan the Terrible. In: Slovar' knizhnikov i knizhnosti Drevney Rusi [The Dictionary of Scribes and Booklore of Ancient Russia]. Leningrad, Nauka Publ., 1988, issue 2, part 1, pp. 371-384. (In Russ.)

20.Perepiska Ivana Groznogo s Andreem Kurbskim [Correspondence of Ivan the Terrible with Andrey Kurbsky]. Moscow, Nauka Publ., 1981. 430 p. (In Russ.)

21. Popovich A. I. Victim "Living" and "Dead". A Topos and the Contradiction of Context in the Books of Ancient Russia of 11th-14th Centuries. In: Letnyaya shkola po russkoy literature, 2019, vol. 15, no. 2-3, pp. 115-135. DOI: 10.26172/25878190-2019-15-2-3-115-135 (In Russ.)

22. Rudi T. R. Topoi of Russian Lives (Typology Issues). In: Russkaya agiografiya: Issledovaniya. Publikatsii. Polemika [Russian Hagiography: Research. Publications. Polemic]. St. Petersburg, Dmitriy Bulanin Publ., 2005, vol. 1, pp. 59-101. (In Russ.)

23. Slovar' knizhnikov i knizhnosti Drevney Rusi [The Dictionary of Scribes and Booklore of Ancient Russia]. St. Petersburg, Dmitriy Bulanin Publ., 2012, issue 2, part 3. 768 p. (In Russ.)

24.Skrynnikov R. G. Tsarstvo terrora [The Kingdom of Terror]. St. Petersburg, Nauka Publ., 1992. 576 p. (In Russ.) 
25. Uvarov K. A. Knyaz' A. M. Kurbskiy - pisatel' («Istoriya o velikom knyaze Moskovskom»): avtoref. dis. ... kand. filol. nauk [Prince A. M. Kurbsky Is a Writer ("The Story of the Grand Prince of Moscow"). PhD. philol. sci. diss. abstract]. Moscow, 1973. 25 p. (In Russ.)

26. Uspenskiy B. A. Poetics of Composition. In: Uspenskiy B. A. Semiotika iskusstva [Uspensky B. A. Semiotics of Art]. Moscow, Shkola "Yazyki russkoy kul'tury" Publ., 1995, pp. 9-218. (In Russ.)

27. Uspenskiy B. A. Tsar' i patriarkh: kharizma vlasti v Rossii (vizantiyskaya model' i ee russkoe pereosmyslenie) [Tsar and Patriarch: Charisma of Power in Russia (Byzantine Model and Its Russian Rethinking)]. Moscow, Shkola "Yazyki russkoy kul'tury" Publ., 1998. 680 p. (In Russ.)

28. Filyushkin A. I. Andrey Mikhaylovich Kurbskiy: prosopograficheskoe issledovanie i germenevticheskiy kommentariy k poslaniyam Andreya Kurbskogo Ivanu Groznomu [Andrey Mikhailovich Kurbsky: Prosopographic Study and Hermeneutic Commentary on the Letters of Andrey Kurbsky to Ivan the Terrible]. St. Petersburg, St. Petersburg State University Publ., 2007. 624 p. (In Russ.)

29. Shmidt S. O. Notes on the Language of the Letters of Ivan the Terrible. In: Trudy Otdela drevnerusskoy literatury [Proceedings of the Department of Old Russian Literature]. Moscow, Leningrad, Academy of Sciences of the USSR Publ., 1958, vol. 14, pp. 256-265. (In Russ.)

30. Hunt P. Ivan IV's Personal Mythology of Kingship. In: Slavic Review, 1993, vol. 52, issue 4, pp. 769-811. (In English)

31. Halperin Ch. J. Ivan the Terrible: Free to Reward and Free to Punish. Pittsburgh, University of Pittsburgh Press Publ., 2019. 360 p. (In English)

32. Madariaga I. Ivan the Terrible. First Tsar of Russia. Yale, Yale University Press Publ., 2006. 526 p. (In English) 